\title{
Interaction of Rahaliya-Ekhedhur groundwater with the aquifer rock, West Razzaza Lake, Central Iraq
}

\author{
Moutaz A. Al-Dabbas ${ }^{1}$
}

Received: 30 April 2016/Accepted: 31 August 2016/Published online: 15 September 2016

(c) The Author(s) 2016. This article is published with open access at Springerlink.com

\begin{abstract}
The groundwater of Dammam aquifer in Rahaliya-Ekhedhur area, West Razzaza, Iraq, was studied to identify the main hydrogeochemical processes and the groundwater-rock interaction. The results indicated that $\mathrm{Na}^{+}$and $\mathrm{SO}_{4}{ }^{2-}$ are the dominant ions in the groundwater. The average contribution of cations in the aquifer is $\mathrm{Na}^{+}+\mathrm{K}^{+}(24.7 \%), \mathrm{Ca}^{2+}(13.9 \%)$, and $\mathrm{Mg}^{2+}(11.4 \%)$, while anions contribution is $\mathrm{SO}_{4}{ }^{2-}(23.0 \%), \mathrm{Cl}^{-}(20.7 \%)$, and $\mathrm{HCO}_{3}{ }^{-}(6.3 \%)$. The groundwater characterized by neutral to slightly alkaline hard water, excessively mineralized, and slightly brackish water type. Rock-water interaction processes are identified to include dissolution of carbonates, sulfates, halite, and clay minerals, leaching, and cation exchanges, with little impact of evaporation.
\end{abstract}

Keywords Hydrogeochemistry · Dammam aquifer · West Razzaza $\cdot$ Iraq

\section{Introduction}

It is absolutely necessary taking into account the fact that all the hydrometeorological processes parameters are expected to change accordingly with the effects of the global climate change. The quality of groundwater is of equal importance to quantity when it depends upon its purpose, and thus, the needs for drinking water, industrial water, and irrigation water vary widely (Todd 2007).

Moutaz A. Al-Dabbas

profaldabbas@yahoo.com

1 College of Science, University of Baghdad, Aljaderia, Baghdad University Post Office, P. O. Box: 47138, Baghdad, Iraq
The permanent storage of groundwater in RahaliyaEkhedhur Area was recommended by Hassan and AlKubaisi (2002) and Al-Muqdadi (2012), to be utilized in the agriculture purposes. Some studies that were done on this area are those provided by Al-Bassrawi (1996), AlFatlawi (2000), and Hussain et al. (2015), which focus on groundwater management and hydrogeological setting in the Rahaliya -Ekhedhur Area and western desert. Three formations are affected the chemistry of groundwater in the study area; Dammam, Euphrates, and Nfayil Formations. The groundwater in the study area is stored within the Dammam aquifer which underlies the Euphrates and Nfayil Formations. The Euphrates Formation has discontinuous marl and clay layer covered the Dammam Formation. The Dammam Formation is composed of shallow neritic carbonates (limestone and dolomite) of middle to upper Eocene, and overlies by the Euphrates Formation (lower Miocene) of shallow marine carbonates with bedded marly limestone (Awadh et al. 2016). The Nfayil Formation of marl, limestone, and claystone (middle to lower Miocene), and the recent deposits (thin sand sheets and gypsiferouse soil) form a discontinuous layer over the old geological formations, and they may add ions to the Al-Dammam aquifer with the percolated rain water through Abu-Jir fault zone and other fault system in the area (Awadh et al. 2013; Thabit et al. 2014). The study area is located in Rahaliya-Ekhedhur Area, Anbar, and Karbala governorates, to the west of the Razzaza Lake in the central part of Iraq. The area is extending from Rahhalia to the Ekhedhur passing through Shithatha city between latitudes $\left(32^{\circ} 25^{\prime}-32^{\circ} 50^{\prime}\right)$ North and longitudes $\left(43^{\circ} 15^{\prime}-43^{\circ} 40^{\prime}\right)$ East (Fig. 1). The aim of this study is to describe groundwater-rock interaction and identify the hydrogeochemical processes.

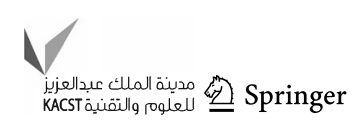




\section{Materials and methods}

Sixteen groundwater samples were collected during October 2013 from Rahaliya-Ekhedhur groundwater wells that drilled in the Dammam aquifer (Fig. 1). Depth of groundwater wells ranges from 45 to $140 \mathrm{~m}$, according to Hassan and Al-Kubaisi (2002). The measurements were done using procedure of APHA (1998). All samples were analyzed for major ions $\mathrm{K}^{+}, \mathrm{Na}^{+}, \mathrm{Ca}^{2+}, \mathrm{Mg}^{2+}, \mathrm{CO}_{3}{ }^{2+}$, $\mathrm{HCO}^{3-}, \mathrm{SO}_{4}{ }^{2-}$, and $\mathrm{Cl}^{-}$. Sodium and potassium was analyzed using flame photometer. Calcium, magnesium, chloride, carbonate, and bicarbonate were determined by titrimetric method. Sulfate was determined using of spectrophotometer. The hydrogen number $(\mathrm{pH})$, electrical conductivity (EC), TDS, and temperature $(T)$ were measured directly in the field using, HANA (HI 9811). The analytical accuracy was calculated according to Hem (1985) and Al-Hamadani (2009), accordingly, accuracy of results is accepted. Hydrochemical formula was computed as average formula based on Kurlolov formula which was referred in Ivanov et al. (1968).

\section{Results and discussion}

\section{Groundwater characterization}

The results reflect that the groundwater is classified as a neutral to slightly alkaline, where the $\mathrm{pH}$ values ranges from 7.1 to 7.8 according to Matthess (1982) (Table 1). Wide range of variation was found in EC and TDS. The EC is ranging from 2560 to $3850 \mu \mathrm{s} / \mathrm{cm}$ reflecting excessively mineralized water (Detay 1997), while the TDS varies from 1740 to $2750 \mathrm{ppm}$ indicating a slightly brackish water (Todd 2007). In addition, according to the results, the groundwater in the studied area is classified as very hard water due to wide exposures of limestone in the recharge area according to Todd 2007. The dominant cation is $\mathrm{Na}^{+}$ with average of $24 \%$, while the dominant anion is $\mathrm{SO}_{4}{ }^{2-}$ with average of $23 \%$ from the total ions (Fig. 2). The ionic constituents of the groundwater in the Dammam aquifer are displayed by Stiff diagram of each studied well within the exposed geological formations (Fig. 3a). The sodium concentration (epm) ranges from 13.6 to 25.6, while sulfate varied between 10.1 and 31.8. The source of sulfate is believed to be from dissolving of secondary gypsum of Nfayil Formation, gypsiferous soil and to the partial mixing of water coming from multi-aquifer through the horizontal and vertical groundwater movement within the fault system in the area (Fig. 3b). The Dammam aquifer in the study area is characterized by $\mathrm{Na}-\mathrm{SO}_{4}$ water type represented by the following hydrochemical formula:

$$
2176 \frac{\mathrm{SO}_{4}(46.0) \mathrm{Cl}(41.4)}{\mathrm{Na}(49.4) \mathrm{Ca}(27.8) \mathrm{Mg}(22.8)} 7.29 \text {. }
$$

The access sodium obviously supports that the marine origin from deep source that has been mixed with meteoric

Table 1 The hydrochemical parameters of groundwater in the study area

\begin{tabular}{|c|c|c|c|c|c|c|c|c|c|c|}
\hline $\begin{array}{l}\text { Well } \\
\text { no. }\end{array}$ & $\begin{array}{l}\mathrm{Na}^{+}+\mathrm{K}^{+} \text {epm } \\
(\%)\end{array}$ & $\begin{array}{l}\mathrm{Mg}^{2+} \text { epm } \\
(\%)\end{array}$ & $\begin{array}{l}\mathrm{Ca}^{2+} \text { epm } \\
(\%)\end{array}$ & $\begin{array}{l}\mathrm{Cl}^{-} \text {epm } \\
(\%)\end{array}$ & $\begin{array}{l}\mathrm{SO}_{4}{ }^{2-} \text { epm } \\
(\%)\end{array}$ & $\begin{array}{l}\mathrm{HCO}_{3}{ }^{-} \mathrm{epm} \\
(\%)\end{array}$ & $\begin{array}{l}\text { TDS } \\
(\mathrm{ppm})\end{array}$ & $\begin{array}{l}\mathrm{EC}(\mu \mathrm{s} / \\
\mathrm{cm})\end{array}$ & $\mathrm{pH}$ & $\begin{array}{l}\text { T.H } \\
\text { (ppm) }\end{array}$ \\
\hline 1 & 56.4 & 21.6 & 22.0 & 55.6 & 31.3 & 13.1 & 2350 & 3850 & 7.20 & 839.4 \\
\hline 2 & 69.4 & 13.3 & 17.3 & 36.6 & 51.3 & 12.1 & 1740 & 2560 & 7.21 & 339.8 \\
\hline 3 & 70.0 & 14.2 & 15.4 & 40.5 & 42.4 & 17.1 & 2204 & 2900 & 7.11 & 389.5 \\
\hline 4 & 69.5 & 12.5 & 17.5 & 36.6 & 51.2 & 12.2 & 2226 & 2950 & 7.22 & 338.4 \\
\hline 5 & 37.1 & 31.9 & 31.0 & 37.4 & 56.8 & 5.7 & 2100 & 2800 & 7.21 & 632.5 \\
\hline 6 & 45.1 & 23.6 & 31.4 & 41.1 & 44.8 & 14.0 & 2305 & 2800 & 7.80 & 978.1 \\
\hline 7 & 45.5 & 23.3 & 31.2 & 40.5 & 44.5 & 14.5 & 2220 & 2800 & 7.3 & 962.4 \\
\hline 8 & 44.4 & 23.3 & 32.4 & 33.4 & 51.6 & 11.0 & 2238 & 3670 & 7.36 & 1032.8 \\
\hline 9 & 71.8 & 12.7 & 15.5 & 40.3 & 42.5 & 17.3 & 2000 & 3670 & 7.40 & 366.4 \\
\hline 10 & 27.3 & 33.3 & 39.4 & 43.5 & 51.5 & 5.0 & 2260 & 2750 & 7.20 & 852.1 \\
\hline 11 & 39.0 & 31.5 & 29.5 & 54.0 & 37.4 & 8.7 & 2228 & 2700 & 7.20 & 979.6 \\
\hline 12 & 36.9 & 32.0 & 31.1 & 35.1 & 59.1 & 5.6 & 2000 & 2750 & 7.30 & 632.4 \\
\hline 13 & 42.0 & 24.6 & 33.5 & 35.7 & 53.2 & 11.1 & 2450 & 3480 & 7.22 & 972.5 \\
\hline 14 & 48.2 & 22.2 & 29.5 & 29.8 & 46.3 & 23.1 & 2750 & 3260 & 7.25 & 813.7 \\
\hline 15 & 44.2 & 23.1 & 33.5 & 40.4 & 45.2 & 14.4 & 2113 & 2750 & 7.25 & 802 \\
\hline 16 & 71.0 & 13.8 & 15.2 & 40.5 & 42.4 & 17.1 & 2476 & 3260 & 7.11 & 389.6 \\
\hline Min. & 27.3 & 12.5 & 15.2 & 29.8 & 31.3 & 5.0 & 1740 & 2560 & 7.11 & 338.4 \\
\hline Max. & 71.0 & 33.3 & 33.5 & 55.6 & 59.1 & 23.1 & 2750 & 3850 & 7.80 & 1032.8 \\
\hline Mean & 49.4 & 22.8 & 27.8 & 41.4 & 46.0 & 12.6 & 2176.2 & 3042.3 & 7.29 & 700.3 \\
\hline
\end{tabular}



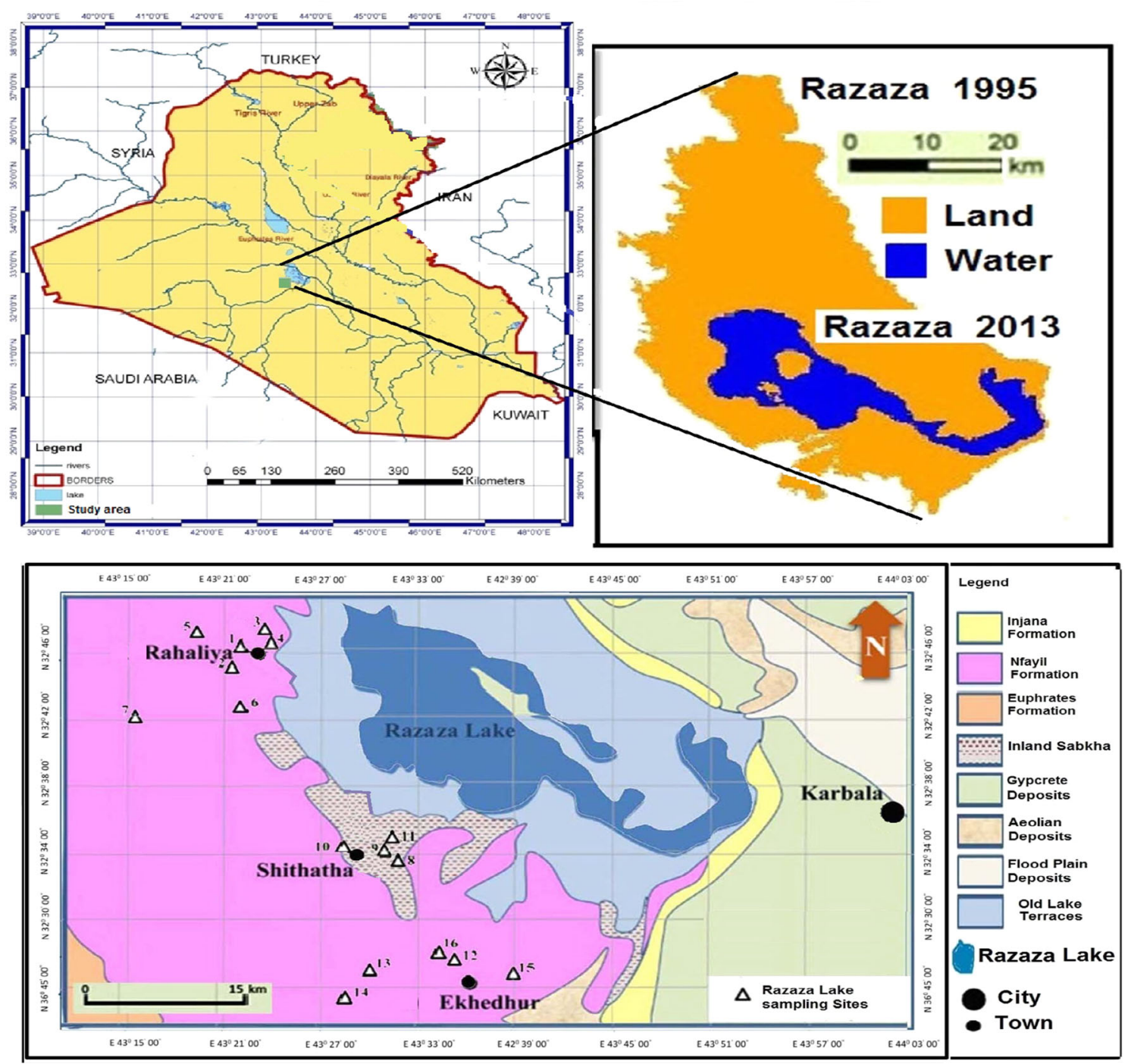

Fig. 1 Simplified geological map shows the location of the study area and the groundwater wells (after Sissakian, et al. 2000)

water is the source of the Dammam aquifer. An earth alkai waters rich by $\mathrm{Ca}^{2+}$ and $\mathrm{Mg}^{2+}$ with increase alkalis and prevailing sulfate and chloride can be described by Piper diagram that displays of $86 \%$ groundwater samples (Field A in Fig. 4), but the remnant $14 \%$ represents an alkali water rich by $\mathrm{Na}$ with prevailing sulfates and chloride (Field B in Fig. 4).

\section{Groundwater-rock interaction}

The aquifer characterization may interpret by the hydrochemical functions to conclude the rock-water interaction (Subramani et al. 2010). The results reflect high $\mathrm{Na}^{+}$concentration relative to the $\mathrm{Cl}^{-}$value that represented by the average value (1.29) of $\mathrm{rNa}^{+} / \mathrm{rCl}^{-}$. This finding indicates the presence of another source of $\mathrm{Na}$ rather than halite and provides an evidence of dissolution of terrestrial minerals during partial leaching (Table 2). The ratio of $\mathrm{rCa}^{2+} / \mathrm{rMg}^{2+}$ with the average value (1.66) is between of seawater (0.14) and rainwater (7.14) (El-Sayed et al. 2012). Such finding reflects the interaction between water and aquifer rocks causing dissolution of carbonates (limestone and dolomite) under acidic $\mathrm{pH}$ conditions ( $\mathrm{pH}$ of rainwater). The dissolution of the gypsum and anhydrite in the aquifer indicated by $\mathrm{rSO}_{4}{ }^{2-} / \mathrm{rCl}^{-}$ratio with the high average value (1.2) in groundwater samples reflects.

The graphic relation of $\mathrm{Ca}^{2+}+\mathrm{Mg}^{2+}$ versus $\mathrm{SO}_{4}{ }^{2-}+\mathrm{HCO}_{3}{ }^{-}$shown in Fig. 5 is being close to the $1: 1$ line which is obvious the normal case if the dissolutions of calcite, dolomite, and gypsum are the dominant reactions in the aquifer. Ion exchange tends to shift points to the right due to an excess of $\mathrm{SO}_{4}{ }^{2-}+\mathrm{HCO}_{3}{ }^{-}$(Cerling et al. 1989; Fisher and Mulican 1997). While the reverse is true, the 


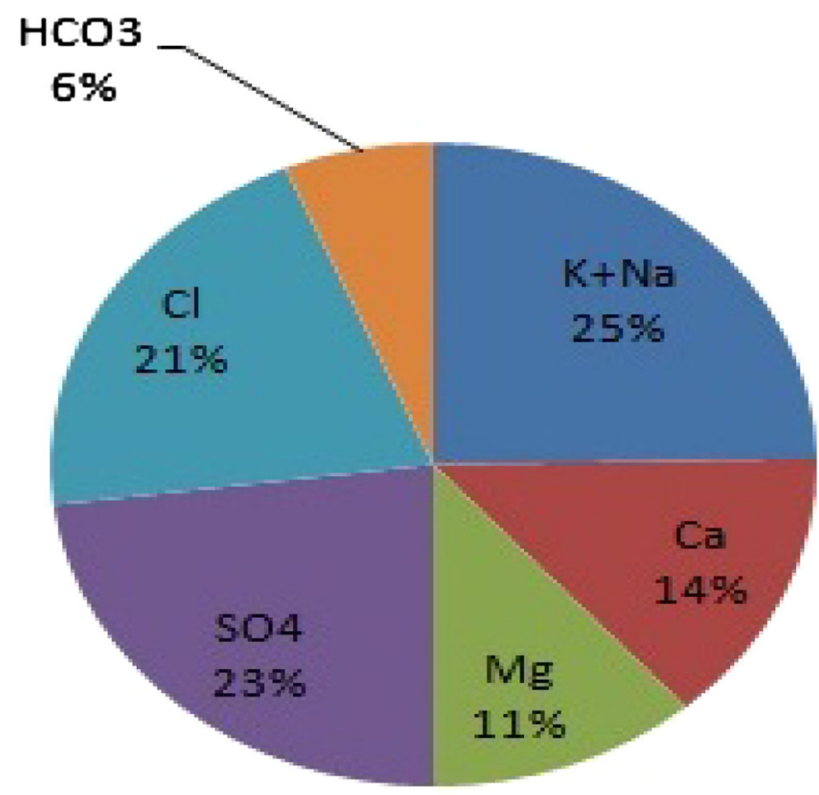

Fig. 2 Pie diagram displays the average ionic constituents of groundwater in the Dammam aquifer

points will be shifted to the left due to a large excess of calcium and magnesium relative to sulfates and bicarbonates. The groundwater samples of the Dammam aquifer are shifted to the right as resulted from the common gypsum dissolution and may be attributed partially to the cation exchange with clay mineral (Fig. 5).

The ratio of $\mathrm{Ca} / \mathrm{Mg}$ indicates dissolution of dolomite, if it is equal 1.0, but a higher ratio reflects a greater calcite contribution (Maya and Loucks 1995). In this study, the very high $\mathrm{Ca}^{2+}+\mathrm{Mg}^{2+}$ molar values (more than 5.0 to less than 21) indicate the contribution of $\mathrm{Ca}^{2+}$ and $\mathrm{Mg}^{2+}$ to groundwater due to dissolution of calcite, dolomite, and gypsum (Fig. 6).

The increase in salinity with the relative increase in both calcium and magnesium ions indicating that the carbonate weathering in the aquifer was done by chloride-bearing water (Fig. 7). The major sources of $\mathrm{Ca}^{2+}$ are limestone, dolomite, dolomitic limestone, marl, and gypsum, whereas the $\mathrm{Mg}^{2+}$ sources are dolomitic limestone and dolomite. Carbonates of the Euphrates and Dammam Formations, and gypsum of the Nfayil Formation have been subjected to dissolution, then added $\mathrm{Ca}^{2+}, \mathrm{Mg}^{2+}, \mathrm{CO}_{3}{ }^{2-}$, and $\mathrm{SO}_{4}{ }^{2-}$ to the groundwater system as recharged water during rainfall as well as leaching during irrigation.

Silicate weathering can be understood by estimating the ratio between $\left(\mathrm{Na}^{+}+\mathrm{K}^{+}\right)$and total cations (El-Sayed et al. 2012). The distribution pattern of the groundwater samples is plotted along the $\mathrm{Na}^{+}+\mathrm{K}^{+}=0.5$ total cations (Fig. 8). It clearly reflects the halite dissolution, because $\mathrm{Na}^{+}$contributes by $24 \%$ from the total ions and $\mathrm{K}^{+}$ contributes by only $1 \%$.

\section{Groundwater chemistry control}

The $\mathrm{Na} / \mathrm{Cl}$ molar ratio can be used to identify the evaporation process in groundwater (Subramani et al. 2010). The molar ratio of $\mathrm{Na} / \mathrm{Cl}$ against $\mathrm{EC}$ plot was used to understand the dominant chemical processes in the Dammam aquifer. A horizontal line resulted from the plot of $\mathrm{Na} / \mathrm{Cl}$ against EC means concentration via evaporation (Jankowski and Acworth 1997). The molar ratio of $\mathrm{Na} / \mathrm{Cl}$ is still constant and approximately close to 1.0 in the case of halite dissolution, but the greater than 1.0 means that $\mathrm{Na}$ released may be from silicate weathering (Mayback 1987).

Based on this ratio, 14 groundwater samples out of 16 samples are greater than 1.0 having an average of 1.29 for the values varied from 0.6 to 1.9 (Table 2; Fig. 9). This means the presence of other processes beside halite dissolution that might be existed; it would be silicate (clay minerals) dissolution. The distribution pattern of the molar ratio of $\mathrm{Na} / \mathrm{Cl}$ versus electrical conductivity displays a random trend meaning lack of evaporation effect on chemistry of groundwater in Dammam aquifer. Groundwater has unique chemistry due to several processes like soil/rock-water interaction during recharge and groundwater flow, prolonged storage in the aquifer, dissolution of mineral species (Hem 1985).

The results reflect about $90 \%$ of groundwater samples fell above the 1:1 line indicating an additional source of $\mathrm{Na}^{+}$rather halite which may be attributed to the ionic exchange in clay minerals and silicate weathering (Fig. 10).

Gibbs (1970) diagram was used to discriminate the evaporation, dilution, and rock weathering as hydrochamical processes affected groundwater of the Dammam aquifer. The Gibbs diagram was mainly shared the chemical weathering and evaporation, and it is indicated that the groundwater chemistry in the Dammam aquifer was mainly controlled by weathering reactions (Fig. 11a, b). Gibbs diagram shows that there is no dilution process which reflects the lack of the amount of annual precipitation in the recharge area that feed the Dammam aquifer.

\section{Enrichments of ions}

The interpretation of the probable source rock was done following many sequential steps and based on the computed results given in Table 3 (Hounslow 1995). To describe source ions and rocks affected groundwater chemistry, the chemical functions are used as follows:

1. The values of the ratio of $\mathrm{Na} /(\mathrm{Na}+\mathrm{Cl})$ indicates that there is a possible contribution of the sea water in the Dammam aquifer in $56 \%$ wells, where the values of this ratio are more than 0.5 . 

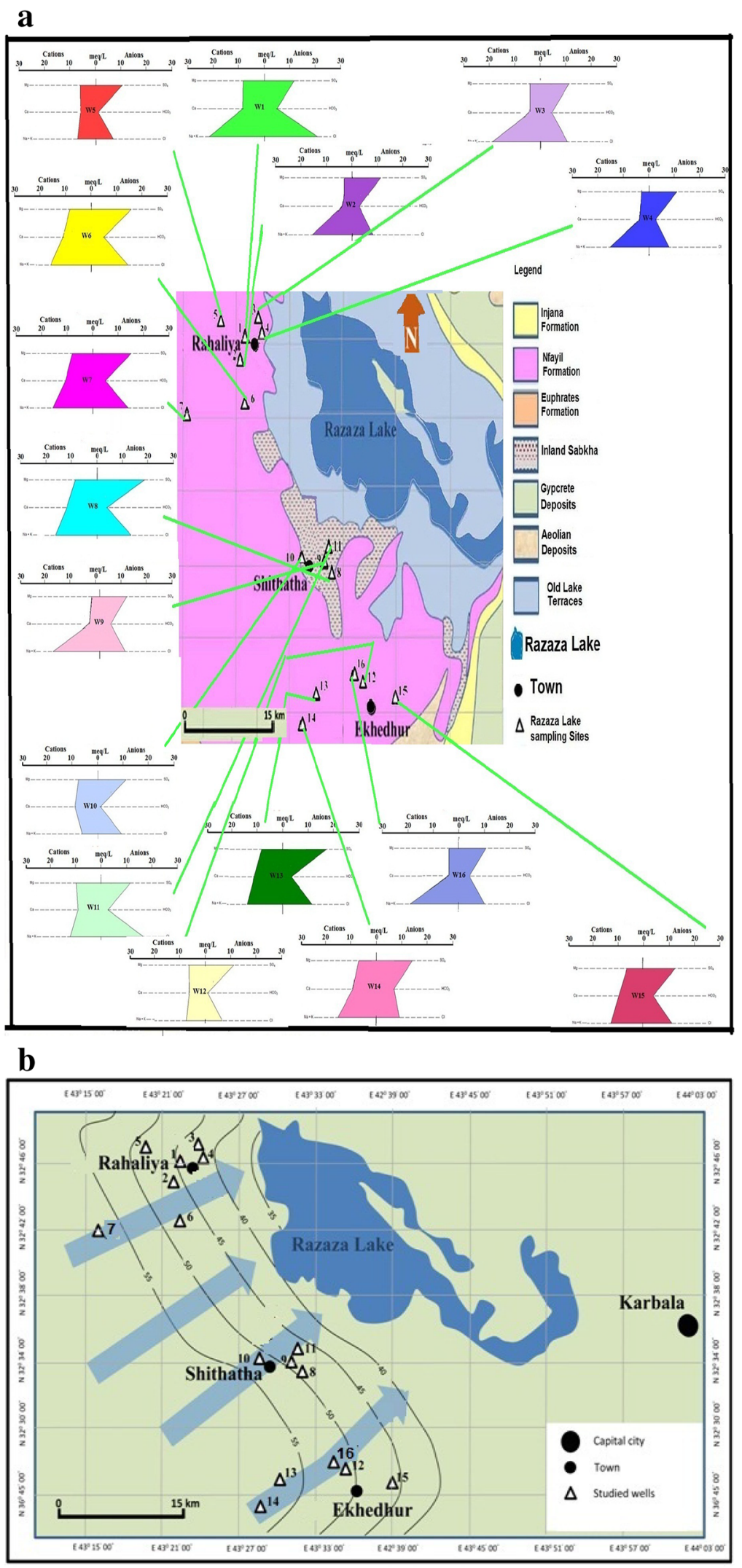

Fig. 3 a Stiff diagram shows the chemistry of groundwater in the Dammam aquifer with the geological formations outcropped in the study area and studied groundwater wells (Stiff 1951). b Groundwater flow of the Dammam confined aquifer 


\section{Piper Diagram}

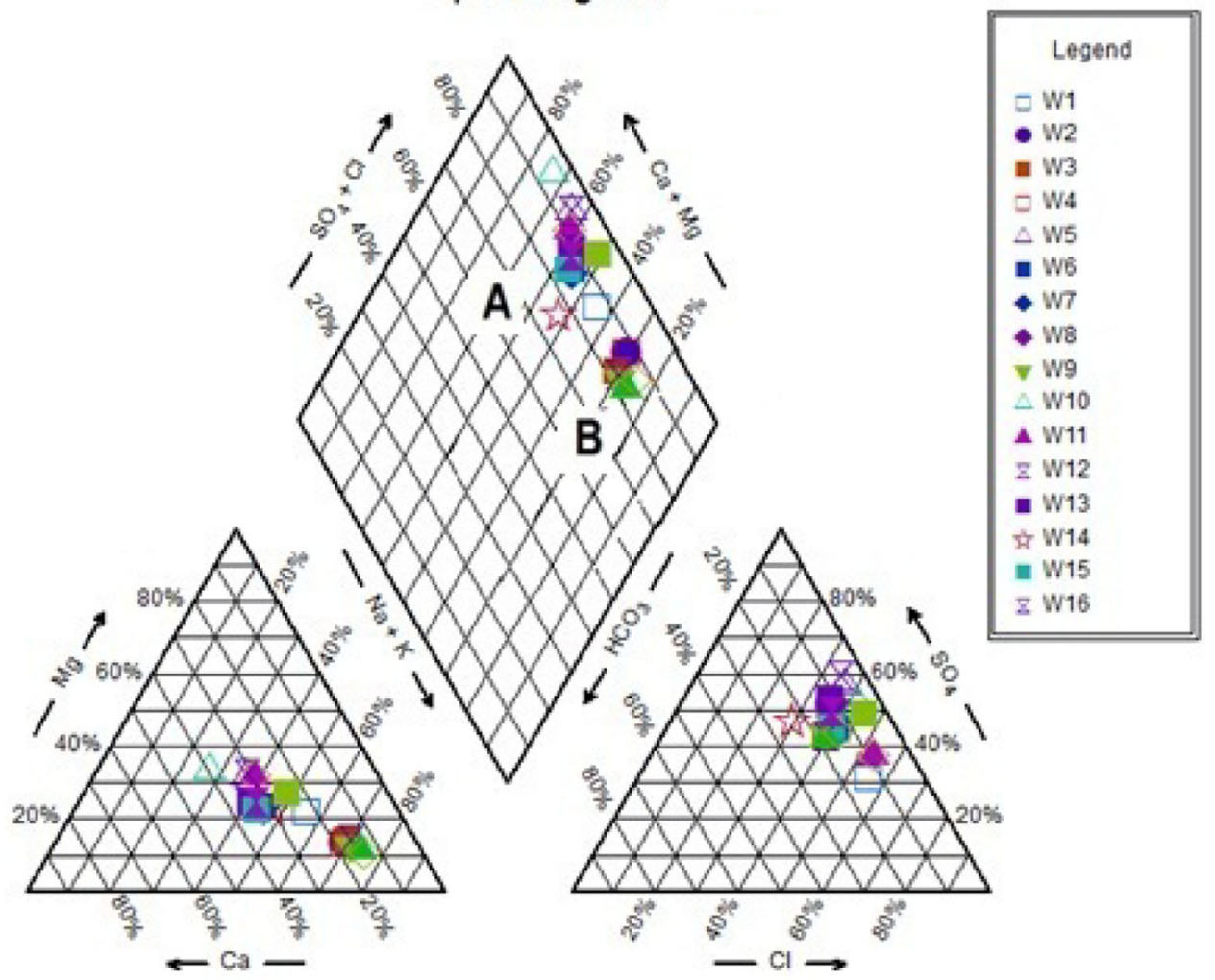

Fig. 4 Piper diagram display groundwater facies in the Dammam aquifer (Piper 1944)

Table 2 Hydrochemical function (in mole) of groundwater in the Dammam aquifer

\begin{tabular}{lllllllllll}
\hline S. no. & $\mathrm{Ca} / \mathrm{Mg}$ & $\mathrm{SO}_{4}^{\prime} \mathrm{Cl}$ & $\mathrm{Ca}+\mathrm{Mg}$ & $\mathrm{SO}_{4}+\mathrm{HCO}_{3}$ & $\mathrm{Cl}$ & $\mathrm{Na}+\mathrm{K}$ & $\mathrm{Na} / \mathrm{Cl}$ & $\mathrm{Na}$ & $\mathrm{Cl} /(\mathrm{Cl}+\mathrm{HCO})$ & $\mathrm{Na} /(\mathrm{Na}+\mathrm{Ca})$ \\
\hline 1 & 1.02 & 0.6 & 16.8 & 16.73 & 20.85 & 21.7 & 1.02 & 21.29 & 0.8 & 0.7 \\
2 & 0.3 & 1.4 & 6.8 & 14.06 & 7.883 & 15.4 & 1.9 & 15.07 & 0.8 & 0.8 \\
3 & 1.08 & 1.0 & 7.8 & 15.77 & 10.28 & 18.1 & 1.7 & 17.8 & 0.7 & 0.8 \\
4 & 1.35 & 1.4 & 6.8 & 14.08 & 7.911 & 15.4 & 1.9 & 15.07 & 0.7 & 0.8 \\
5 & 0.9 & 1.4 & 12.6 & 11.08 & 7.15 & 7.4 & 1.0 & 7.162 & 0.9 & 0.5 \\
6 & 1.3 & 1.1 & 19.6 & 20.7 & 14.4 & 16.1 & 1.08 & 15.64 & 0.7 & 0.6 \\
7 & 1.3 & 1.1 & 19.2 & 20.45 & 14.34 & 16.2 & 1.09 & 15.68 & 0.7 & 0.6 \\
8 & 1.4 & 1.4 & 20.6 & 22.86 & 13.66 & 16.4 & 1.2 & 16.16 & 0.8 & 0.6 \\
9 & 1.2 & 1.1 & 7.3 & 14.7 & 10.14 & 18.7 & 1.8 & 18.37 & 0.7 & 0.8 \\
10 & 1.2 & 1.2 & 17.0 & 12.37 & 9.6 & 6.4 & 0.6 & 6.121 & 0.9 & 0.5 \\
11 & 9.5 & 0.7 & 19.5 & 14.97 & 17.29 & 12.5 & 0.7 & 12.16 & 0.9 & 0.6 \\
12 & 0.97 & 1.6 & 12.6 & 12.32 & 6.756 & 7.4 & 1.04 & 7.162 & 0.9 & 0.5 \\
13 & 1.36 & 1.5 & 19.4 & 21.69 & 11.89 & 14.1 & 1.2 & 13.77 & 0.8 & 0.6 \\
14 & 1.3 & 1.6 & 16.3 & 21.47 & 9.295 & 15.2 & 1.6 & 14.77 & 0.5 & 0.6 \\
15 & 1.3 & 1.1 & 16.1 & 16.93 & 11.57 & 12.7 & 1.1 & 12.55 & 0.7 & 0.6 \\
16 & 1.08 & 1.05 & 7.8 & 14.77 & 10.28 & 19.1 & 1.8 & 18.63 & 0.6 &
\end{tabular}

2. The values of the ratio of $\mathrm{Mg} /(\mathrm{Ca}+\mathrm{Mg})$ greater than 0.5 indicates dolomite dissolution and calcite precipitation, but if less than 0.5 indicates limestone- dolomite weathering. The computed values of this function (less than 0.5) reflect the limestone-dolomite weathering as a dominant process. 
Fig. 5 Relation between $\mathrm{Ca}^{2+}+\mathrm{Mg}^{2+}$ and $\mathrm{SO}_{4}{ }^{2-}+\mathrm{HCO}_{3}{ }^{-}$in groundwater of the Dammam aquifer

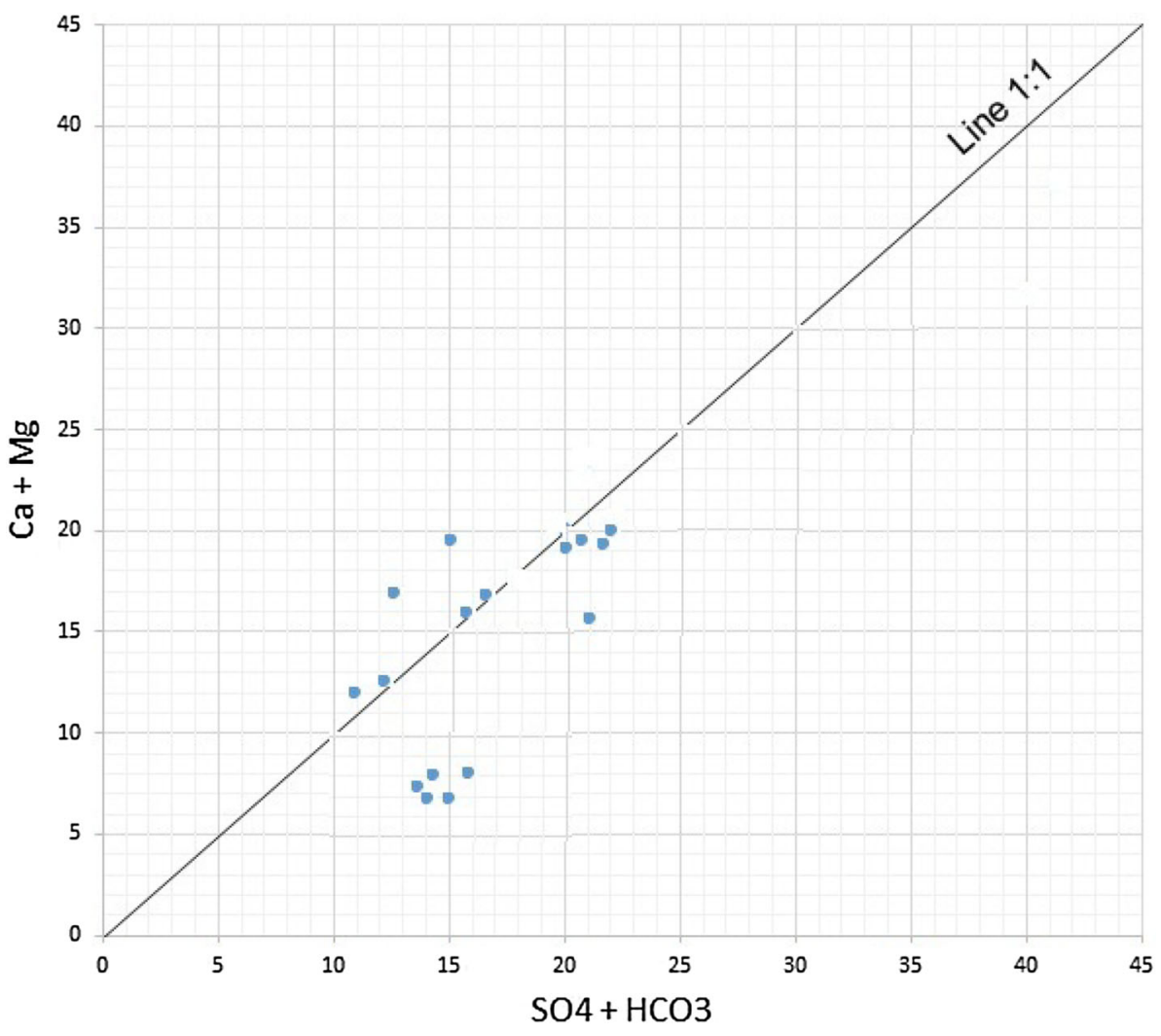

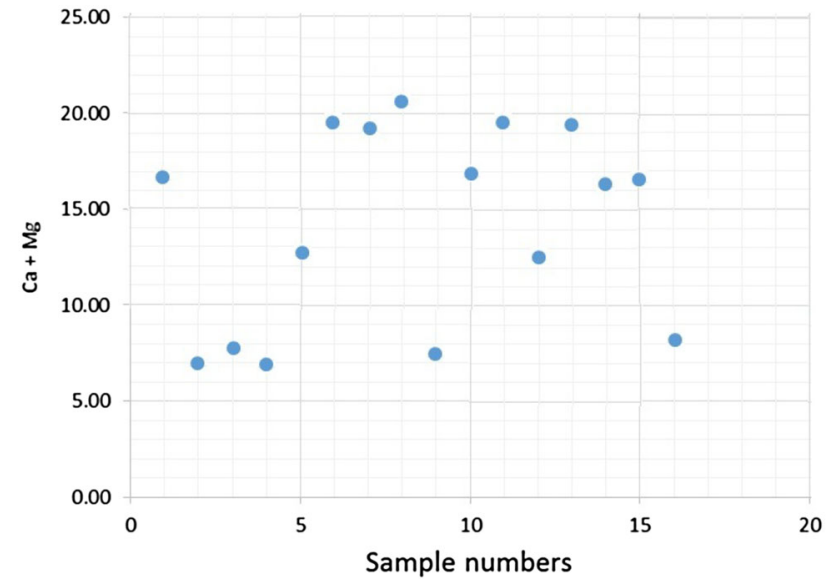

Fig. 6 The scatter diagram of of $\mathrm{Ca}^{2+}+\mathrm{Mg}^{2+}$ molar values in groundwater samples of the Dammam aquifer

3. If the calculated values of the ratio of $\mathrm{Ca} /\left(\mathrm{Ca}+\mathrm{SO}_{4}\right)$ are less 0.5 , it means calcium removal by ion exchange or calcite precipitations, but if it is greater than 0.5 indicating calcium source rather than gypsum-carbonate or silicates. In this study, values of this function are less than 0.5 indicating $\mathrm{Ca}^{2+}$ removal by ion exchange or calcite precipitation. $\mathrm{pH}$ values do not support the $\mathrm{Ca}^{2+}$ precipitation in the Dammam aquifer.

4. The values of the ratio of $\mathrm{Mg} /\left(\mathrm{Ca}+\mathrm{SO}_{4}\right)$ are less than of 0.5 in the Dammam aquifer indicating contribution

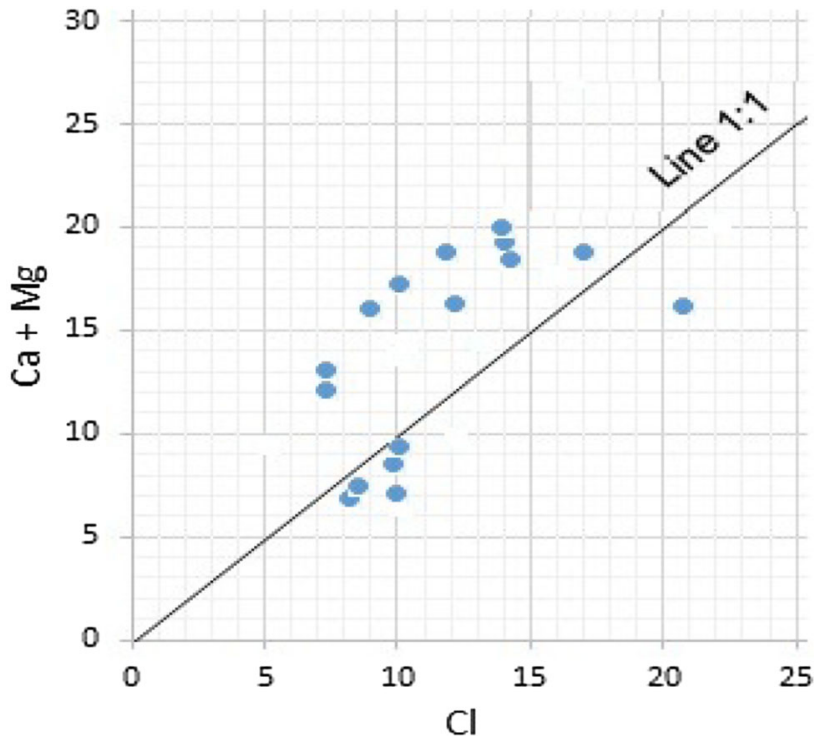

Fig. 7 Relationship between $(\mathrm{Ca}+\mathrm{Mg})$ and $\mathrm{Cl}$ in groundwater of the Dammam aquifer

calcite and gypsum more than contribution of dolomite.

5. If the computed ratio of $(\mathrm{Ca}+\mathrm{Mg}) / \mathrm{SO}_{4}$ fall within $0.8-1.2$ indicating dedolomitization. The result reflects that there is an effective dedolomitization process indicated by about $70 \%$ of the computed ratios of this function for the groundwater samples. 


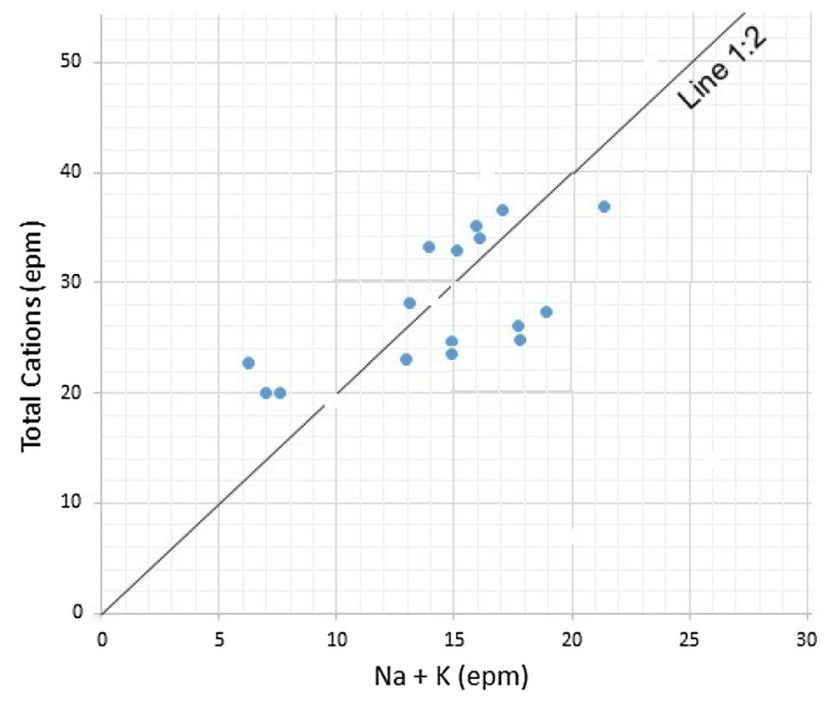

Fig. 8 Relationship between $(\mathrm{Na}+\mathrm{K})$ and total cations in mole

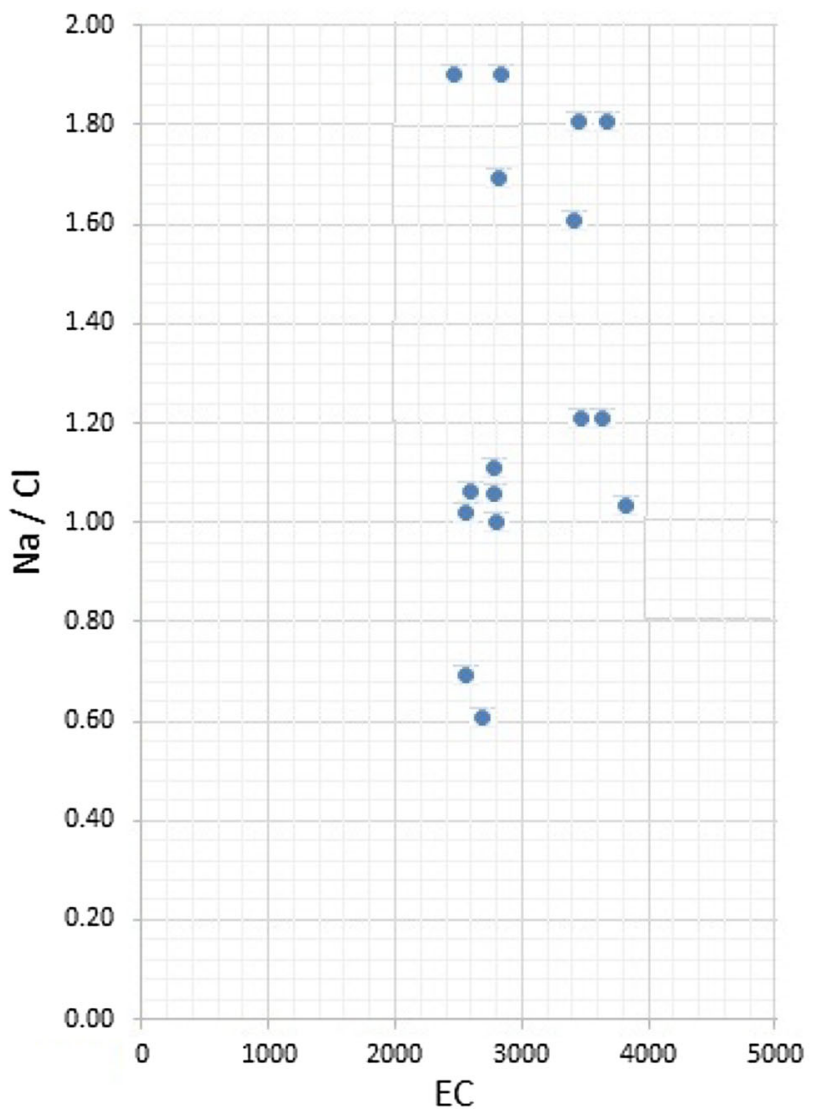

Fig. 9 Distribution pattern of $(\mathrm{Na} / \mathrm{Cl})$ against $\mathrm{EC}$ in groundwater of Dammam aquifer

6. If the value of TDS greater than $500 \mathrm{ppm}$, it mostly indicates carbonate weathering or brine or seawater, and if less than $500 \mathrm{ppm}$, it indicates silicate weathering. TDS data refer to the carbonate weathering as

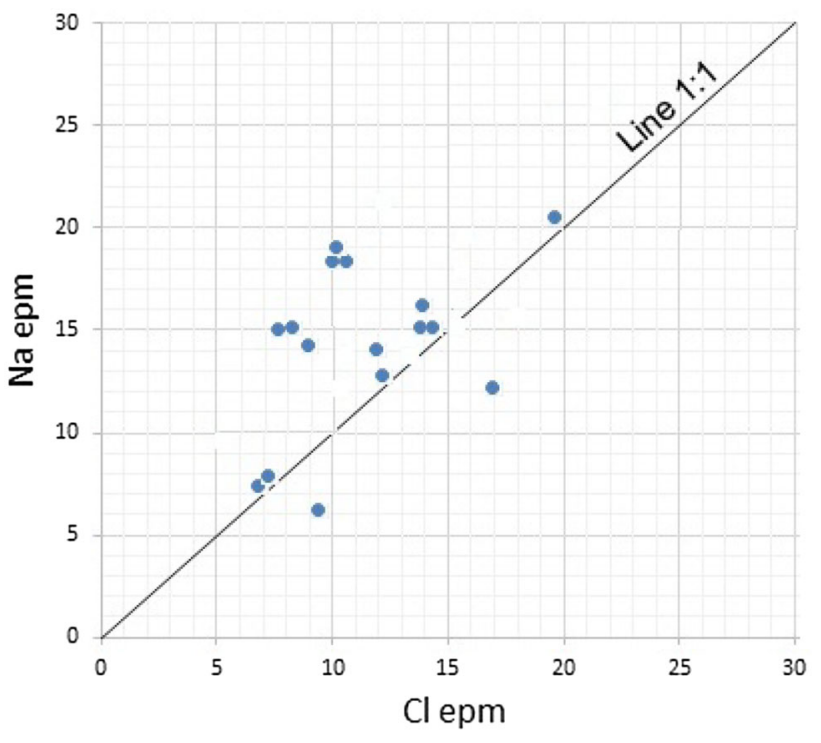

Fig. 10 relationship between the molar ration of $\mathrm{Na}$ and $\mathrm{Cl}$

the values in the Dammam aquifer are greater than $500 \mathrm{ppm}$.

7. If the values of the ratio of $\mathrm{Cl} / \sum$ anions are less than 0.8 , it indicates rock weathering. Accordingly, the rock weathering was the dominant process in Dammam aquifer, so as the values of these ratios are less than 0.8 .

8. If the calculated value of the ratio of $\mathrm{HCO}_{3} / \sum$ anions is less than 0.8 , it indicates seawater or brine. Consequently, all computed data are less than 0.8 , then it indicates a brine water may affected by connate or fossils water that might be feeding along the fault plane of AJFZ.

\section{Evaluation of groundwater quality}

In general, the variation of the groundwater quality can be attributed to the lithological and mineralogical contents of the geological formation as well as to the spatial variation in controlling factors that are responsible for sedimentation and dissolution of different minerals. The existence of several economic projects (industrial and agricultural products), such as the production of washed sand factory and fractionalizing gravels factory, were added more reasons for groundwater contamination. Moreover, some of the studied wells were located in area affected by human activity and domestic sewage effluent to the water sources; therefore, unsatisfactory for drinking may be due to the level of organic matter in the water. Possible sources of contamination include leaking septic systems, runoff from agricultural lots and organically enriched water such as industrial effluents or from decaying plant materials and 

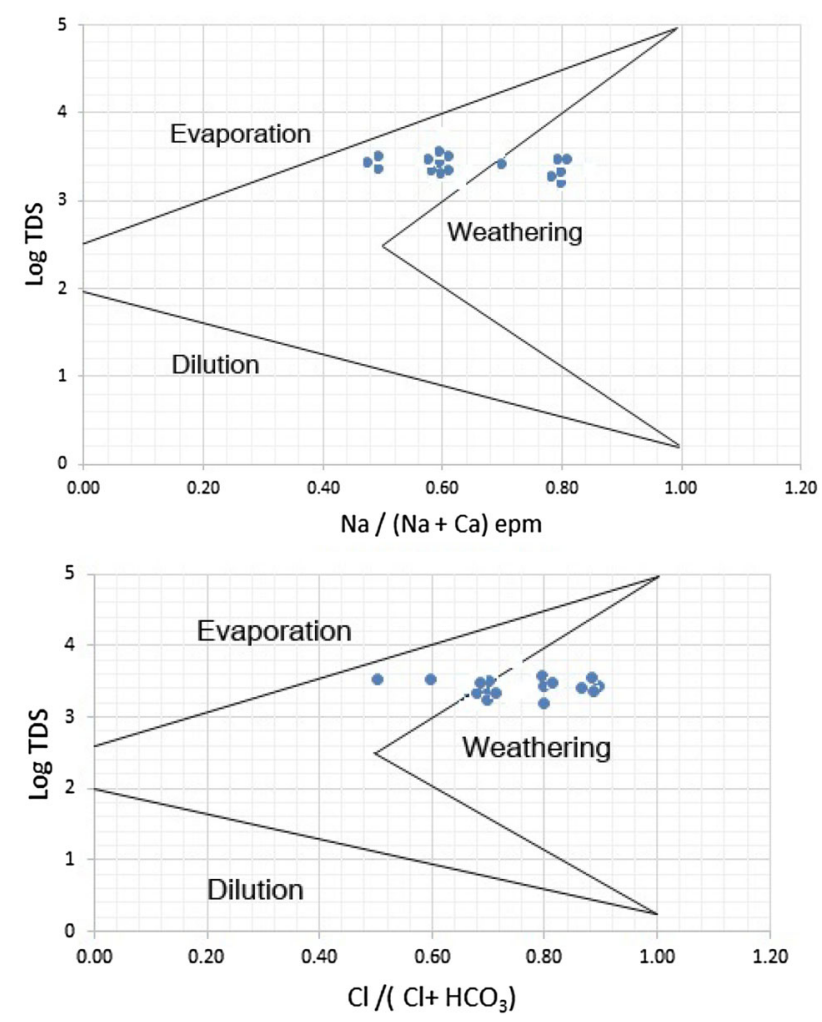

Fig. 11 A and B: Gibbs diagrams classification of groundwater samples of the Dammam aquifer

soils. According to Al-Dabbas et al. (2016), the groundwater chemical analyses indicated that they are unsuitable for human drinking purposes according to the World Health Organization standard (WHO 2008). The microbial analysis results indicated that about $50 \%$ of groundwater samples are contaminated according to their total microbial count; therefore, all the groundwater samples are unsuitable for drinking purposes (Al-Dabbas et al. 2016).

\section{Conclusions}

(a) The groundwater of Dammam aquifer is characterized by a meteoric water origin, neutral to slightly alkaline $\mathrm{pH}$ of excessively mineralized and slightly brackish water. The common water type is $\mathrm{Na}-\mathrm{SO}_{4}$, where groundwater constituent is ordered as: $\mathrm{Na}>\mathrm{Ca}>\mathrm{Mg}$ $(100 \%) ; \quad \mathrm{SO}_{4}>\mathrm{Cl}>\mathrm{HCO}_{3} \quad(91 \%)$, but $\mathrm{Cl}>$ $\mathrm{SO}_{4}>\mathrm{HCO}_{3}(9 \%)$.

(b) Groundwater samples can be described as an earth alkai water rich by $\mathrm{Ca}$ and $\mathrm{Mg}$ with increase alkalis and prevailing sulfate and chloride by $86 \%$, while the rest represents an alkali water rich by $\mathrm{Na}$ with prevailing sulfates and chloride.

(c) Multi-chemical processes were affected the groundwater chemistry in the study area. These are dissolution of carbonate and evaporate rocks, silicate weathering, the ionic exchange between clay minerals and groundwater as well as leaching by precipitation and irrigation returns flow. Fertilizers may provide additional ions to the groundwater aquifer. Dissolution is the common chemical process, and there is no precipitation for any mineral species.

(d) Groundwater-rock interaction in the Dammam aquifer is represented by the contribution of calcite and

Table 3 Computed function for the source rock interpretation

\begin{tabular}{|c|c|c|c|c|c|c|c|c|}
\hline S. no & $\mathrm{Na} /(\mathrm{Na}+\mathrm{Cl})$ & $\mathrm{Mg} /(\mathrm{Ca}+\mathrm{Mg})$ & $\mathrm{Ca} /\left(\mathrm{Ca}+\mathrm{SO}_{4}\right)$ & $\mathrm{Mg} /\left(\mathrm{Ca}+\mathrm{SO}_{4}\right)$ & $(\mathrm{Ca}+\mathrm{Mg}) / \mathrm{SO}_{4}$ & $\mathrm{Cl} / \sum$ anions & $\mathrm{HCO}_{3} / \sum$ anions & TDS ppm \\
\hline 1 & 0.5 & 0.5 & 0.4 & 0.38 & 1.4 & 0.55 & 0.13 & 2350 \\
\hline 2 & 0.6 & 0.44 & 0.26 & 0.2 & 0.63 & 0.37 & 0.21 & 1740 \\
\hline 3 & 0.6 & 0.47 & 0.26 & 0.24 & 0.7 & 0.4 & 0.17 & 2204 \\
\hline 4 & 0.6 & 0.4 & 0.26 & 0.21 & 0.46 & 0.37 & 0.13 & 2226 \\
\hline 5 & 0.48 & 0.5 & 0.38 & 0.4 & 1.2 & 0.37 & 0.05 & 2100 \\
\hline 6 & 0.5 & 0.4 & 0.4 & 0.29 & 1.24 & 0.41 & 0.14 & 2305 \\
\hline 7 & 0.5 & 0.4 & 0.4 & 0.29 & 1.2 & 0.41 & 0.14 & 2220 \\
\hline 8 & 0.53 & 0.4 & 0.38 & 0.28 & 1.1 & 0.41 & 0.11 & 2238 \\
\hline 9 & 0.6 & 0.45 & 0.27 & 0.20 & 0.63 & 0.4 & 0.17 & 2000 \\
\hline 10 & 0.38 & 0.46 & 0.45 & 0.38 & 1.5 & 0.43 & 0.05 & 2260 \\
\hline 11 & 0.4 & 0.51 & 0.46 & 0.49 & 1.1 & 0.53 & 0.20 & 2228 \\
\hline 12 & 0.5 & 0.5 & 0.34 & 0.36 & 1.1 & 0.34 & 0.09 & 2000 \\
\hline 13 & 0.54 & 0.4 & 0.38 & 0.42 & 1.1 & 0.36 & 0.05 & 2450 \\
\hline 14 & 0.6 & 0.43 & 0.38 & 0.29 & 1.1 & 0.3 & 0.11 & 2750 \\
\hline 15 & 0.52 & 0.4 & 0.19 & 0.28 & 1.2 & 0.4 & 0.22 & 2113 \\
\hline 16 & 0.64 & 0.5 & 0.26 & 0.27 & 0.7 & 0.4 & 0.14 & 2476 \\
\hline
\end{tabular}


gypsum in supplying ions more than contribution of dolomite.

(e) The main source of sulfate is dissolving of gypsum. The evaporation and oxidation-reduction are not effective process in the Dammam aquifer, where oxidizing sulfide is not detected in the study area.

Open Access This article is distributed under the terms of the Creative Commons Attribution 4.0 International License (http:// creativecommons.org/licenses/by/4.0/), which permits unrestricted use, distribution, and reproduction in any medium, provided you give appropriate credit to the original author(s) and the source, provide a link to the Creative Commons license, and indicate if changes were made.

\section{References}

Al-Bassrawi NH (1996) Hydrogeology of Razzaza lake. Unpub. Ph.D. Thesis, College of Science, University of Baghdad, Iraq (In Arabic), p 128

Al-Dabbas MA, Al-Khafaji R, Al-Qaraghuli SA (2016) Trace elements and microbial contamination of groundwater and its evaluation in the Rahaliya-Ekhedhur area, west Razzaza lakeCentral Iraq. In: Proceedings of the 4th international conference of association of genetic and environmental resources conservation, Egypt

Al-Fatlawi AN (2000) Hydrochemical study of Shithatha area under white valley. M.Sc. Thesis, College of Science, University of Baghdad (in Arabic), p 113

Al-Hamadani JA (2009) Hydrochemical effect of ground water due to irrigation and drainage projects in Tawuq sub-Basin (South of Karkuk North of Iraq). Unpublished M.Sc. University of Baghdad, College of Science, p 120

Al-Muqdadi SW (2012) Groundwater investigation and modelingwestern desert of Iraq. unpub. Ph.D. Thesis, Freiberg univ. Germany

APHA (1998) Standard methods of the examination of water and wastewater, 20th edn. American Public Health Association, Washington, DC

Awadh SM, Ali KK, Alazawi AT (2013) Geochemical exploration using surveys of spring water, hydrocarbon and gas seepage, and geobotany for determining the surface extension of Abu-Jir Fault Zone in Iraq: a new way for determining geometrical shapes of computational simulation models. $\mathrm{J}$ Geochem Explor 124:218-229

Awadh SM, Abdulhussein FM, Al-Kilabi JA (2016) Hydrogeochemical processes and water-rock interaction of groundwater in AlDammam aquifer at Bahr Al-Najaf, Central Iraq. Iraqi Bull Geol Mining 12(1):1-15

Cerling TE, Pederson BL, Damm KLV (1989) Sodium-Calcium ion exchange in the weathering of shales: implications for global weathering budgets. Geology 17:552-554
Detay M (1997) Water wells. Implementation, maintenance and restoration. Wiley, London, p 379P

El-Sayed MH, Abo El-Fadl MM, Shawky HA (2012) Impact of hydrochemical processes on groundwater quality, WadiFeiran, South Sinai, Egypt. Aust J Basic Appl Sci 6(3):638-654

Fisher RS, Mulican WF (1997) Hydrochemical evolution of sodiumsulfate and sodium-chloride groundwater beneath the Northern Chihuahuan desert, Trans-Pecos, Texas, USA. Hydrogeol J 10(4):455-474

Gibbs RJ (1970) Mechanisms controlling world water chemistry. Science 17:1088-1090

Hassan AH, Al-Kubaisi QY (2002) The fourth axis and the third subaxis, natural recharge for the groundwater in the western desert, 2nd part, pp 308-310

Hem JD (1985) Study and interpretation of the chemical characteristics of natural water, 3rd edn. U.S. Geological Survey WaterSupply Paper, 2254, p 263

Hounslow AW (1995) Water quality data analysis and interpretation. Lewis, New York, pp 45-128

Hussain MH, Al-Ansari NA, Knutson S (2015) Groundwater pollution potential in part of the Western Desert, Iraq. J Earth Sci Geotech Eng 5(14):1-17. ISSN:1792-9040 (print), 1792-9660 (online) Science press Ltd

Ivanov VV, Barbanov LN, Plotnikova GN (1968) The main genetic types of the earth's crust mineral water and their distribution in the USSR. In: Inter Geol Cong of 23rd. Sessions Czechoslovakia, vol 12, p 33

Jankowski J, Acworth RI (1997) Impact of debris-flow deposits on hydrogeochemical process and the development of dry land salinity in the Yass River catchment, New South Wales, Australia. Hydrogeol J 5(4):71-88

Matthess G (1982) The properties of groundwater. Wiley, New York, p 406

Maya AL, Loucks MD (1995) Solute and isotopic geochemistry and groundwater flow in the Central Wasatch Range, Utah, USA. J Hydrol 172:31-59

Mayback M (1987) Global chemical weathering of surficial rocks estimated from river dissolved loads. Am J Sci 287:401-428

Piper AM (1944) A graphic procedure in the geochemical interpretation of water analyses. Trans Am Geophys Union 25:914-923

Stiff HA (1951) The interpretation of chemical water Analyses by means of patterns. J Pet Technol 3(10):15-17

Subramani T, Rajmohan N, Elango L (2010) Groundwater geochemistry and identification of hydrogeochemical processes in a hardrock region, Southern India. Environ Monit Assess 162:123-137

Thabit JM, Al-Yasi AI, Al-Shemmari AN (2014) Estimation of hydrolic parameters and porosity from geoelectrical properties for fractured rock aquifer in Middle Dammam Formation at Bahr Al-Najaf Basin, Iraq. Iraqi Bull Geol Mining 10(2):41-57

Todd DK (2007) Groundwater hydrology, 2nd edn. Wiley, India, p 535

WHO (2008) Guidelines for drinking water quality, 3rd edn, vol 1, recommendations. UN publication, Geneva, p 516 